\title{
Pomegranate cultivation in Mukteshwar, Uttarakhand - A new Initiation for Economic Upliftment
}

Narayan Singh

Received : 25.02.2020; Revised : 09.03.2020; Accepted : 25.03.2020

\begin{abstract}
Horticulture was an important and prime activity of farmers in Uttarakhand Himalaya,but presently, the horticulture farming facing great stress due to climate change, land use change, unscientific management and un-willingness of farmers. The present study was under taken to know the scope of cluster base Pomegranate cultivation. Different issues identified as a community vision for the development of this promising area. One year growth data was validated and measured in this study.
\end{abstract}

KEY WORDS : IHR, Orchard, Management, Varieties, Climate Change, Uttarakhand

How to cite this paper : Singh, Narayan (2020). Pomegranate cultivation in Mukteshwar, Uttarakhand - A new Initiation for Economic Upliftment. Internat. J. Com. \& Bus. Manage, 13(1) : 21-25, DOI: 10.15740/HAS/IJCBM/13.1/21-25. Copyright@ 2020: Hind AgriHorticultural Society. 